\title{
The Difference of Authority between Satpol PP and Polri in Creating General Involvement
}

\author{
Tri Suhartanto ${ }^{1}$, Indra Perwira ${ }^{2}$ \\ ${ }^{1}$ Ph.D. Student at Faculty of Law, University of Indonesia \\ ${ }^{2}$ Faculty of Law, Padjadjaran University, Bandung, Indonesia \\ Email: tri_sil@yahoo.com
}

\begin{abstract}
This study aims to analyze the differences in law enforcement authority between Civil Service Police Unit (Satpol Pamong Praja/ Satpol PP) and Indonesian National Police (Polri) in creating public order and peace of society and how the differences could cause an overlap in their implementation. The research method used is normative juridical legal research using a statutory, conceptual, and comparative approach. The results showed that differences in law enforcement authority between Satpol PP and Polri are in creating public order and peace of society. Satpol PP has an authority to maintain public order, while the National Police is more concerned with maintaining domestic security; Meanwhile, in carrying out their duties, the Satpol PP often overlaps and clashes with other law enforcers, especially the National Police. It cannot be denied that it often happens that the National Police finally have to become a "fire brigade" when carrying out their duties. The Satpol PP has to clash with the community, which then arises an anarchic situation. When in situations that could lead to further disturbance in security and public order, the National Police finally intervened. What often happened was that the National Police collided with the community because of the anarchist situation that had developed too far.
\end{abstract}

Keywords: Authority, Satpol PP, Polri, Order, Security.

\section{A. INTRODUCTION}

The provisions of Article 18 paragraph (2) of the 1945 Constitution of the Republic of Indonesia (referred to as the Indonesian Constitution 1945) regulates that provincial, regency, and city-regional governments regulate and administer their government affairs according to the principle of autonomy and co-administration. Under Article 18 paragraph (5), the 1945 Indonesian Constitution 1945) regulates that Regional Governments exercise autonomy to the broadest possible extent, except for governmental affairs, which are determined as central affairs. In the context of carrying out autonomy and assistance tasks, regional governments are given the right by Article 18 paragraph (6) of the 1945 Constitution of the Republic of Indonesia to establish Regional Regulations (Perda) and other regulations.

Regional regulation is a form of the legal product of Regional Government in carrying out Regional Government affairs based on the principle of autonomy and duty of assistance. A Regional Regulation, in substance, can contain provisions including: first, concerning matters related to the principle of autonomy; and second, matters related to co-administration. Matters related to the principle of autonomy refer to all government affairs that have been decentralized. The implementation of a government affair has a relatively high degree of independence based on its initiative under the aspirations of the local community. Peraturan Daerah (District 
Law), as a manifestation of autonomy, is more visible as an independent system. Matters related to co-administration tasks contain provisions implementing regulations from the provisions of the legislation, which are of a higher degree. However, these provisions are technically still adjusted to the conditions of the local community. This Perda is based on the principle of autonomy. The task of coadministration simply makes it easier to analyze because the existence of the Perda is a subsystem of national laws.

Perda may contain a maximum fine from six months up to a maximum fine of Rp. 50,000,000.00 (fifty million rupiahs). In practice, there are many Perda that contain criminal sanction, as mentioned above, such as Perda on public order, Perda on the prohibition of prostitution, Perda on the prohibition of gambling, Perda on decency about the prohibition on liquor and others. In general, these aspects have been regulated in the third book of the Criminal Law Act (Indonesian Criminal Code) concerning violations. However, in general, the provisions contained therein are quite behind the current developments. Like for example, the emphasis contained in maintaining peace and order but still not comprehensive illustrates what describes the peace and public order, for example only looking at the problem of controlling street vendors and controlling billboards.

Implementation of public order and peace of society is a problem for the Government. The matter was then decentralized to autonomous regions as regulated in Article 65 paragraph (1) letter b of Law Number 23 of 2014 concerning Regional Government (from now on referred to as Law No. 23 of 2014). As a decentralized affair, the regions can manage the affairs' technical implementation independently. The legal form of the implementation of centralized affairs is regulated further in a Regional Regulation. In order to uphold public order and public peace, it is not uncommon for Perda to impose sanctions on both administrative and criminal sanctions. Criminal sanctions for local regulations require professional staff as law enforcers and tactically become part of the regional government structure. The problem raises a separate dilemma between the authority of the administration of public order and the peace of society, which is the matter of regional Government on the one hand. However, on the other hand, the appointment and formation of investigators are included in the scope of central government affairs in the field of justice.

Based on the obligations held by the Regional Government based on Law no. 23 of 2014 and the main tasks inherent in the Police make the two institutions partners in the implementation of peace and order of the people in the area, then in the implementation of fostering security and public order; it is necessary to have an integrated concept between the Regional Government and the Police in the region. Sadjijono said that the formulation of a Perda is relating to the obligations and tasks. The task involving two institutions, so that it has a binding legal force, is sustainable. There is no conflict with one another in order to realize the State's aspirations in guaranteeing the fulfillment of the rights of Indonesian citizens. A study conducted by the Impartial Team found that the Satpol PP was an extension of the political 
interests of regional heads who often collaborated with capital and other interests under the pretext of controlling and evicting projects. In the notes presented to the media, he said that there are three reasons he said deserves to be the basis for the dissolution of Satpol PP. The three reasons are the Satpol PP's aggressive nature, which cannot be eliminated because it has been inherited as part of the spirit of the Satpol PP corps. With the shallow professional ability and very loose regulations, the future will grow only in a militaristic character. Second, the existence of Satpol PP overlaps with the Police's duties, which also carry out Satpol PP functions. The function of providing security must be returned to the Police, not only on a national scale but up to the corner of Indonesia.

This existence of Satpol PP also overlaps the authority of law enforcement. The function of law enforcement in the government environment should be carried out by the National Police and specialized institutions such as civil servant investigators. The reasons put forward by the Impartial Team still need to be explored further. However, at least the empirical facts about the acts of violence committed by Satpol PP have become an indication for us all that there is something wrong in the use of Satpol PP in order to become a means towards prosperity for the community. As an agent to enforce regional regulations, Satpol PP must carry out the general Government's functions. This purpose is to lead to conditions that enable citizens to participate in activities so that efforts to achieve prosperity and improve the quality of life can be achieved.

The authority of Satpol PP stated in Article 256 of Law No. 23 of 2014, which regulates that Satpol PP was formed to uphold Regional Regulations and Regional Regulations, conduct public order and peace, and conduct community protection. This provision is regulated in Article 1, number 1, and Article 1, number 2 PP No. 16 of 2018. Article 1 number 1 PP No. 16 of 2018 mentions the Civil Service Police Unit, called Satpol PP, is a regional apparatus established to enforce Regional Regulations and Regional Head Regulations, conduct public order and peace, and carry out community protection. Article 1 number 2 PP No. 16 of 2018 regulates the Civil Service Police (Pol PP) is a member of the Satpol PP as a Regional Government apparatus. They occupied by civil servants and given the duties, responsibilities, and authorities under statutory regulations in the enforcement of Regional Regulations and Regional Head Regulations, implementation of public order and peace, and community protection.

Based on the description above, it can be concluded that under the mandate of Law No. 23 of 2014 firmly states that the authority possessed by Satpol PP is as a regional law enforcer, creating public order and peace and community protection. Meanwhile, the National Police according to Law Number 2 of 2002 challenge the Indonesian National Police ( Law No. 2 of 2002 ) has a state government function in the field of maintaining security and public order, law enforcement, protection, protection, and service to the community (das sollen). However, in reality (das Sein), some apparatuses create public order and peace and protection of the people outside Satpol PP and Polri, namely the Security Guard (Security Unit), Kamra (Hansip), and 
patrollers form what is referred to as surveillance. Based on the gap between das sollen and das sein mentioned above, the researcher is interested in examining the differences in law enforcement authority between Satpol PP and Polri in creating public order and public peace.

The purpose of this study is to analyze: first, the difference in law enforcement authority between Satpol PP and Polri in creating public order and public peace; and secondly, differences in law enforcement authority between Satpol PP and Polri can cause an overlap in their implementation.

\section{B. METHODOLOGY}

This research uses normative legal research with the statute approach and the comparative approach. The legislative approach is carried out by examining all laws and regulations relating to the problems (legal issues) being faced. A comparative approach is used because it compares the regulatory authority of Satpol PP and the authority of the National Police in creating public order and public order. The doctrines will clarify ideas by providing legal understandings, legal concepts, and legal principles relevant to the problem. Data and legal materials used refer to secondary data that includes primary legal materials, consisting of various statutory regulations, jurisprudence, and conventions related to the authority of Satpol PP, as well as secondary and tertiary legal materials. This research is seeking the developments that occur in differences in law enforcement authority between Satpol PP and Polri in creating public order and public peace. This study also uses primary data, i.e., data obtained directly from respondents or informants related to differences in law enforcement authority between Satpol PP and Polri in creating public order and peace.

Data collection is done by searching for literature (library research), both extensively and intensively. Literature research aims to examine, research, and trace secondary data in legal materials. Legal materials are normative-perspective. It is used to study legal issues related to the substance of legal regulations. The acts regulate the authority of Satpol PP and Polri. Based on their binding strength, they are classified as primary legal materials, secondary legal materials, and materials tertiary law. The data analysis technique used is a juridical analysis that is an analysis based on theories, concepts, and legislation.

\section{RESULT AND DISCUSSION}

\section{The Authority of Satpol PP in Creating Public Order and Peace in the Community}

The Satpol PP and Polri authorities will first discuss here. One of the regional government apparatuses that aim to assist regional heads in enforcing regional regulations and implementing public order and peace of society is Satpol PP. The formation of the Satpol PP was born from several provisions in Article 256 of Law No. 23 of 2014. The existence of this Satpol PP regulated by Government Regulation Number 16 of 2018 concerning the Civil Service Police Unit (PP No. 16 of 2018). 
Satpol PP, as a regional apparatus, has a very strategic role in strengthening regional autonomy and public services in the regions. PP 16 of 2018 guarantees the implementation of Satpol PP's duties in the enforcement of Regional Regulations and Regional Regulation. The implementation of public order, peace, and community protection need to be improved, both in terms of institutional and human resources. Besides, the existence of Satpol PP in the administration of regional Government is expected to help legal certainty and facilitate the development process in the regions.

The authority of Satpol PP is regulated in Article 7 PP No. 16 of 2018, which mentions in carrying out its duties and functions, Satpol PP is authorized to: Conducting disciplinary measures against members of the community, apparatus, or legal entities that violate local laws or local regulations; Acting on a community member, apparatus or legal entity that disturbs public order and public order; Carry out investigative actions against members of the public, apparatus or legal entity suspected of violating the Regional Regulations and Regional Regulations; and Carry out administrative actions against community members, apparatuses, or legal entities that violate the Regional Regulations or Regional Regulations.

Based on the provisions mentioned above, it can be said that the Satpol PP's authority, among others, is to enforce Regional Regulations and Regional Regulations, conduct public order and peace and conduct community protection. Legitimate authority, when viewed from where that authority is obtained according to FA, Stroink \& Steenbeek, can be seen in two sources of authority: attributive authority and delegation authority. Both ways the government organs in obtaining authority are used as a basis or theory to analyze the authority of the state apparatus in carrying out its authority. Attributive authority is usually outlined or derived from the distribution of state power by the 1945 Constitution of the Republic of Indonesia, usually in connection with the transfer of new authority. In contrast, delegated authority is authority originating from the delegation of a government organ to another organ based on statutory regulations and concerning the delegation of existing authority (by an organ has gained attributive authority to another organ, so logically it is always preceded by attribution.

The authority of Satpol PP is the authority to maintain the existence of organizing public order and peace, as well as organizing community protection. The task of the Regional Government is mandated to the Civil Service Police Unit (Satpol $\mathrm{PP})$ in the area concerned.

Meanwhile, the most critical Polri authority comes from the provision of Article 30 paragraph (4) of the Indonesian Constitution 1945 which states that the Indonesian National Police as a state instrument that maintains the security and order of the community must protect, protect, serve the community, and enforce the law. The Indonesian Constitution 1945 Indonesia stated that the Indonesian National Police (National Police) be appointed by the State to provide security guarantees for all Indonesian citizens.

Article 30 paragraph (4) Indonesian Constitution 1945 contains two meanings that, aside from being an organ in this case as a tool of the State, the Police are also 
seen as functions. The National Police as an organ in this matter as a State institution that plays a role in maintaining security, public order and law enforcement which is institutionally led by the Head of the Indonesian National Police (Kapolri) appointed by the President on the recommendation of the National Police Commission with the approval of the DPR. The National Police is seen as an essential function related to their duties and authority. The National Police as an instrument of the State that functions to maintain the security and order of the people with the duties they have to protect, protect, serve the community, and enforce the law.

Article 2 of Law No. 2 of 2002 stipulates that: "The function of the police is one of the functions of the state government in maintaining security and public order, law enforcement, protection, protection, and service to the community."

The function of the National Police in this article emphasizes the governmental functions carried out by the National Police in this matter, the administration of the State, where the National Police acts as executor of duties of the executive or the President regarding the maintenance of public order and security.

Article 5 paragraph (1) of Law No. 2 of 2002 emphasized that the Indonesian National Police is a state instrument that plays a role in maintaining security and public order, enforcing the law, and providing protection, protection, and services to the public context of maintaining domestic security. The Basic Duties of the Indonesian National Police is regulated in Article 13 of Law No. 2 of 2002, namely: maintain public security and order; enforce the law and provide protection, protection, and service to the community.

In carrying out these essential tasks, the National Police of the Republic of Indonesia have the authorities to implementing arrangements, guarding, escorting, and patrolling the community and government activities as needed; carry out all activities in ensuring the security, order and smooth traffic on the road; fostering the community to increase community participation, community legal awareness and community adherence to laws and regulations; participate in the development of national law; maintain order and guarantee public security; coordinate, supervise and provide technical assistance to special Police, civil service investigators, and selfhelp security;carry out investigations and investigations into all criminal acts under the criminal procedure code and other laws and regulations; organizing police identification, police medicine, forensic laboratories and police psychology for the benefit of police duties; protect the safety of body and soul, property, community and the environment from disruption of order and disaster including providing assistance and assistance by upholding human rights;serving the interests of the community for a while before being handled by the agency and the authorities; provide services to the community under their interests within the scope of police duties; andcarry out other tasks under statutory regulations (Article 14 of Law Number 2 of 2002).

In the context of carrying out its duties, the authority of the National Police, in general, is regulated in Article 15 of Law no. 2 of 2002 as follows: receive reports 
and complaints; help resolve community disputes that can disrupt public order; prevent and cope with the growth of community diseases; supervise streams that can cause divisions or threaten national unity and cohesion; issue police regulations within the scope of the administrative authority of the Police; carry out special examinations as part of police actions in the framework of prevention; take the first action at the scene; taking fingerprints and other identities and photographing someone; search for information and evidence; organizing the National Criminal Information Center; issue licenses and/or certificates needed in the context of community service; provide security assistance in hearings and implementation of court decisions, other agencies' activities, and community activities;receive and store findings for the time being.

Based on the description above, the National Police's authority was delivered by the Indonesian Constitution 1945 and Law No. 2 of 2002. The authority of the National Police for security and order obtained by two regulation attribution and delegation. Attribution means the granting of new governmental authority by a provision in the legislation that gives birth to a new authority, as stated by Indoharto. Algemene Bepalingen van Administratief Recht (ABAR), stated that attribution authority is more than the law and given by significant authority to specific organ.

The difference in authority between Satpol PP and Polri mentioned above results in differences in law enforcement authority between Satpol PP and Polri in creating public order and public peace. As is well known, the implementation of public order and the peace of society often clash on differences in perception. The difference in perception includes actions or behaviors that are considered to violate public order and public order as one of the differences in perception that occurs between the Police and Satpol PP based on their respective authority. Sociologically, these differences can lead to social categories. Furthermore, this social category begins the birth of different social perceptions between the Police and other community members in looking at various issues.

The existence of Satpol PP is part of the law enforcement process as a regional government instrument needed to support the successful implementation of regional autonomy. In carrying out their duties, the authority of Satpol PP often overlaps and clashes with other law enforcers, especially the Police. This condition results in friction between the Police's authority as a centralistic apparatus and the Satpol PP, an autonomous Regional Government apparatus. However, the presence of the Satpol PP itself can help the police service in the field. Satpol PP can also carry out judicial functions, namely the Civil Service Police, that meets the requirements can be appointed as a Civil Servant Investigator under statutory provisions.

In carrying out their duties, Satpol PP often overlaps and clashes with other law enforcers, especially the Police. It is undeniable that often the Police finally have to become "firefighters" when in carrying out their duties, the Satpol PP finally has to clash with the community, which then arises an anarchic situation. When in situations that could lead to further disturbance in security and public order, the 
Police finally intervened. What often happens, finally, the police clash with the community because of an anarchist situation that has developed too far.

If seen why this overlap occurs, this is due to a clash of "who" has the authority in carrying out a role in maintaining security and public order. In Article 256 of Law No. 23 of 2014, one of the Regional Head's obligations is to formulate an obligation to maintain public peace and order. On the other hand, the National Police has the main task of maintaining security and public order under the formulation in Article 13 of Law No. 2 of 2002. Thus, the main task of the National Police in the region is also the duty of the Regional Head to carry it out. As long as the concept of maintaining security and order owned by the Regional Head is not in the same vision as the National Police, the collision in the field will have a high probability of continuing. Satpol PP as local government officials often does their work overlapping with the National Police officers who base themselves also on the legal umbrella that shelter them. This condition results in friction between the Police's authority as a centralistic apparatus and the Satpol PP, which are autonomous regional government officials.

Legal basis for Satpol PP, there is nothing crucial to question. From the history of the founding of this country, the presence of Satpol PP always gives color to how bureaucrats run the wheels of Government. The presence of Satpol PP was confirmed based on Law No. 23 of 2014. In Article 256 of Law No. 23 of 2014 regulates that Satpol PP is formed to uphold Regional Regulations and Regional Regulations, conduct public order and peace, and conduct community protection.

The problem under Law No. 23 of 2014 is that Satpol PP is part of the Regional Government. In carrying out its duties, Satpol PP members are directly responsible with the Regional Head, in this case, the Regent, Mayor, or Governor. With this condition, there is no hierarchical or structural relationship between the Provincial Satpol PP and the Regency or City Satpol PP. Besides, because the basis for the formation of Satpol PP is Regional Regulations, it is possible that between regencies or cities, there are specifications within the organization that adjust to the character of the local area.

Based on the above discussion, it can be concluded that the difference in the authority of Satpol PP and Polri in public order and peace is if Satpol PP has the authority to maintain public order. At the same time, the National Police is more concerned with maintaining domestic security.

The term public order, according to Oppusunggu has several different meanings. First, public order in engagement law is a limitation of the principle of freedom of contract. Second, as a critical element in "order and welfare, security" (rust en veiligheid). Third, as a partner of "good morality" (goede zeden). Fourth, as synonyms of "law order" (rechtsorde), or Fifth "justice". Sixth, as an understanding of criminal procedural law f or running a fair trial, the judge's obligation to use the articles of specific legislation is finally (Oppusunggu, 2012)

According to Oppusunggu, public order is different from the public interest. Conceptually, public interest means protecting the interests of the wider community 
or shared interests, which are simultaneously confronted (vis-à-vis) with the interests of groups, groups, or individuals (Oppusunggu, 2012) The public interest becomes, for example, the basis for displacing or taking part or all of one's land to build public facilities and infrastructure. For this purpose, the Government can determine the amount of unilateral compensation under its financial capabilities. Because the eviction is in the public interest, the evicted party may receive the unilateral compensation. In applying public interests, there are practical needs of the community. Meanwhile Flemming said Unlawful act is a recognition of moral responsibility turn into legal liability will relate to the party for payment of compensation for any damaged caused and possible remedies. As cited in (Ahmad \& Rachmawati, 2016) Nevertheless, the public interest is not a basis or excuse reason for the validity of foreign law. Conversely, public order cannot be used as a basis for eviction. The application of public order is a normative and ideal requirement.

Normative juridical references in defining public order and public order are Article 11 PP No. 16 of 2018, which mentions the implementation of public order and peace of society includes the activities of early detection and prevention, guidance and counseling, patrol; security, escort, control, handling demonstrations and mass unrest.

Thus, public order and peace of society is a dynamic situation that allows the Government, Regional Government, and the community to carry out their activities in a calm, orderly and orderly manner. The conditions of public order and peace occur in dynamic conditions; that is, the community actively carries out community life without pressure. In addition to the community, the Government and Regional Governments can also carry out government work well.

There are 8 (eight) scopes of public order and public order which include, among others: orderly roads, green lanes, sidewalks, parks, and other public facilities, orderly rivers, channels, ponds, orderly environment, orderly certain places and businesses, orderly building, social order, orderly health, clean places of entertainment and crowds. The achievement of the eight peace and order can only occur if PP No. 16 of 2018 in its enforcement runs effectively. Meanwhile, the authority of the National Police to maintain internal security is derived from national security. National security refers to the need to preserve and maintain the existence of the State through economic, military, and political as well as diplomacy. Conventionally the concept of national security emphasizes the Government's ability to protect the territorial integrity of the State from threats that come from outside and within the State.

National security is a security concept that explains a condition in which the State physically protects from external threats, and allows the State to be willing and ready to fight. Moreover, it can also be assumed as an attempt by the State to prevent war, primarily through a strategy of building a military force that provides deterrent capabilities. In other words, the definition of security is often based on assumptions with the supremacy of military power as a means of protecting the State from outside military threats. Furthermore, the concept of Homeland Security 
refers to situations or circumstances. The essential elements are sovereignty, territory, population or citizenship, economic base, Government, and constitutional system, and the intrinsic values they hold are guaranteed to exist and can carry out functions according to their objectives without interference or threats from any party.

The concept of Homeland Security is a conception of developing national security through the regulation and implementation of security and welfare (prosperity) that is balanced, harmonious and harmonious in all aspects of life as a whole, holistically and integrated based on Pancasila, the 1945 Constitution, and the Archipelago's Insight. Homeland Security is also essentially a state of mind of a group of people who are bound in a political entity called the State. The State of mind was not formed by itself but was based on the material basis of national capabilities, namely its military strength supported by other national power elements. The nature of domestic security is an embodiment of comprehensive security. The concept of comprehensive security believes that threats can be addressed not only to the territory of the state and state authorities but also to everything that is directly or indirectly related to human welfare in the country concerned.

Comprehensive security places security as a multi-dimensional concept that requires the State to prepare a variety of security actors to manage it. Conceptualization of Homeland Security occurs at least in three directions: first, substantial proliferation, especially when national security is not enough to only struggle with state security but must also provide space for citizens' security; second, sectoral proliferation with the inclusion of various non-territorial scopes such as environmental security, economic security, and energy security; and third, vertical proliferation with the inclusion of non-military dimensions as something considered a threat to internal security, in the limited sense as the security of government sovereignty and in the broadest sense that prioritizes the security of humanity.

The objective of managing Homeland Security is entirely aimed at protecting the whole nation, and all of Indonesia's blood spilled, promoting public welfare, educating the nation's life, and participating in carrying out world order as intended in the Preamble to the 1945 Constitution of the Republic of Indonesia. Indonesia needs to have a Homeland Security strategy to achieve the goal of the Indonesian Constitution. Indonesia's strategic environment continues to change. At least Indonesia must take three essential actions in its national security strategy: (1) making decisions regarding changes in the external and internal; Making; mobilizing resources to carry out the decisions that have been. (2) Playing specific instruments to support the decisions that $h$.

Applying (3) The Domestic Security Strategy to deal with the dynamics of these threats should be prepared by considering the context and escalation of threats, manifestations of conflict, efficiency, and effectiveness in the use of national defense and security resources and respect for human values, democracy, and 
human rights. It is essential to avoid creating conditions of securitization and the use of violent means as a last resort.

\section{Differences in Law Enforcement Authority between Satpol PP and Polri Can Cause Overlapping in Implementation}

As stated earlier, in carrying out their duties, the Satpol PP often overlapped and clashed with other law enforcement agencies, especially the National Police. It cannot be denied that it often happens that the National Police finally have to become a "fire brigade" when in carrying out their duties, the Satpol PP finally has to clash with the community, which then arises an anarchic situation. (Ali, Achmad: 2012) When in situations that could lead to further disturbance in security and public order, the Police finally intervened. What often happened was that the National Police collided with the community because of the anarchist situation that had developed too far.

The legal basis for Satpol PP is nothing crucial to question. Due to the history of the founding of this country, the presence of Satpol PP always gives color to how bureaucrats run the wheels of Government. The problem is, according to Law No. 23 of 2014, Satpol PP is part of the Regional Government, so in carrying out their duties, Satpol PP members are directly responsible with the Regional Head, in this case, the Regent, Mayor or Governor. With this condition, there is no hierarchical or structural relationship between the Provincial Satpol PP and the Regency or City Satpol PP. (Araf, 2015). Besides, because the basis for the formation of Satpol PP is Regional Regulations, it is possible that between regencies or cities, there are specifications within the organization that adjust to the character of the local area.

From a juridical point of view, the existence of Satpol PP is based on Laws, PPs, and Regional Regulations for each region. However, in carrying out the tasks, conflicts may arise due to sharp differences in regional characteristics. Another obstacle from the juridical side is that although both are called Satpol PP and have the same uniform, there is no authority from the Provincial Satpol PP to intervene in the Regency or City Satpol PP. The issues arise when Satpol PP members also PPNS handle a case of violation of a Perda that must consult with the provincial Government (Atmasasita, 2012). Under the provisions, it could not be done, when other interests are more likely/favor the interests of the region concerned. The problem of enforcing local regulations can become a disruption in government administration when there is a conflict of interests from each region or with the provincial Government.

From the facts, what is most crucial to cause chaotic coordination in carrying out security tasks, is the lack of strict rules and regulations that govern the function of public security. The Police should have the main task, as stated in Law No. 2 of 2002. However, in Law No. 23 of 2014, Satpol PP, under the coordination of the Ministry of Home Affairs, explicitly has a security function in enforcing local regulations (Bantoro, 2009). The context of who manages security then becomes the "gray" territory. 
The patterns of relations between the Police and the Regional Government often arise, which are often "uncoordinated" in making decisions about security management. Various institutions that have a policing function have taken the authority of the Police in carrying out the security function. The development of Satpol PP functions that have carried out intelligence functions based on Regulation of the Minister of Home Affairs No. 11/2005 on the Regional Intelligence Community (Kominda) shows that the role of Satpol PP in the security and intelligence functions is like a police task. The proposal that the PP Satpol be armed is also a discourse as a tool for completing work to carry out peace and order.

It turns out that the "security cake" in the era of regional autonomy becomes interesting when various security management institutions such as the Police and institutions that have the task of policing begin to feel comfortable managing the security sector after the separation of the TNI and Polri. A statement also emerged that a security institution outside the Policepolice that has the task of policing might be "more police" than the police institution itself. If explicitly, the legislation governing it gives "more" authority in carrying out the security function. In the context of security sector reform, the most important thing is how to seat each institution proportionally, without any hidden interests. However, this is difficult to do because these vested interests often become the basis for carrying out political interest strategies.

The maintenance of security systems, peace and public order in the Unitary State of the Republic of Indonesia are prepared and organized by the central Government, which is functionally concentrated to officials in regional government units or centralized to the Autonomous Regional Government. It can understand why the conflict, especially in the political aspect, can occur. According to Law No. 2 of 2002, the function of organizing security, peace, and public order is one of the functions of Government carried out by the Police. While the implementation of security, peace, and order development carried out by the Police is delegated in stages to the Regional Police up to the Sector Police level.

This mechanism makes the Police management system must adhere to the national police system. In its implementation, the national police system is considered to be very centralistic. The policy-making mechanism in the Polri organization is still centralized, especially in planning and supervision. While external supervision for now only uses pre-trial mechanisms that tend to be legalistic and formalistic. Responsibility of kamtibmas is carried out by the National Police not only nationally but also for local issues. In the development of security for the regional scope, the Police at the regional level automatically must cooperate with the regional Government, in this case, the provincial and city-regional governments. This collaboration starts with the planning, implementation of supervision stages carried out by the public.

Referring to legal products that concern the security and order of the community, one of the Regional Head's obligations is to maintain the peace and order of the people. While the National Police, as affirmed in Article 13 of Law no. 2 
of 2002, has the main task of maintaining security and public order, enforcing the law, and providing protection, protection, and services to the community. Thus there will be problems, what is the main task of the Police in maintaining security and public order in the area is also an obligation of the Regional Head to run it. Here lies the intersection point, which is one of the Regional Head's obligations to be one of the main tasks of the Police, especially in terms of maintaining security and public order.

There are two "versions" of understanding the level of authority in maintaining public order, which in the end often makes the steps of the Satpol PP clash with the Police, especially when viewed from a political aspect, namely aspects which are the domain of the Police. The reason is apparent because the security scope that is the responsibility of each party will differ because of national and local security.

\section{CONCLUSION}

Based on the discussion that has been stated above, it can be concluded. First, the difference in the authority of law enforcement between Satpol PP and Polri in creating public order and peace of society is if Satpol PP is authorized to maintain public order. At the same time, Polri is more concerned with maintaining domestic security. Public order and public tranquility are dynamic conditions that enable the Government, Regional Government, and the community to carry out their activities peacefully, in an orderly. The conception of domestic security is developing national security through the regulation and implementation of security and welfare (prosperity). They are balancing the harmony in all aspects of life as a whole, holistically and integrated based on Pancasila, the 1945 Constitution of the Republic of Indonesia, and the Archipelago's Insight. Second, in carrying out their duties, the Satpol PP often overlaps and clashes with other law enforcers, especially the National Police. It cannot be denied that it often happens that the National Police finally have to become a "fire brigade" when in carrying out their duties, the Satpol PP finally has to clash with the community, which then arises an anarchic situation. When in situations that could lead to further disturbance in security and public order, the Police finally intervened. What often happened was that the National Police collided with the community because of the anarchist situation that had developed too far.

It is necessary to form a national policy model to maintain public order and public peace and the domestic security system to prevent the emergence and early detection of national security disorders involving the National Police, Regional Government, c.q. Satpol PP, Indonesian National Army (TNI), National Intelligence Agency (BIN), and other Ministries in an integrated manner. In this model, the role of the community must also be a significant concern. 


\section{REFERENCES}

1. Ahmad, R., \& Rachmawati, I. (2016). Liability of a sea carrier in the regulation of ship Collisionunder Indonesian maritime law. International Journal of Current Research, 8(09), 38241-38247.

2. Ali, A. (2012). Menguak Teori Hukum (Legal Theory) dan Teori Peradilan (Judicialprudence) Termasuk Interpretasi Undang-Undang (Legisprudence). Jakarta: Kencana Prenada Media Group.

3. Araf, A. (2015). Dinamika Reformasi Sektor Keamanan: Jakarta: Imparsial.

4. Atmasasmita, R. (2012). Sistem Peradilan Pidana Perspektif Eksistensialisme dan Abolisionisme. Bandung: Bina Cipta.

5. Bandoro, B. (2009). Hubungan Luar Negeri Indonesia dan Strategi Keamanan Nasional, dalam Perspektif Baru Keamanan Nasional. Jakarta: CSIS.

6. Danusastro, S. (2016). Penyusunan Program Legislasi Daerah yang Partisipatif. Jurnal Konstitusi, 9(4), 643-660.

7. Diantha, I. M. P. (2017). Metodologi Penelitian Hukum Normatif dalam Justifikasi Teori Hukum. Jakarta: Prenada Media Group.

8. Djamin, A. (2012). Kedudukan Kepolisian Negara RI dalam Sistem Ketatanegaraan: Dulu, Kini dan Esok. Jakarta: PTIK Press.

9. Fachruddin, I. (2004). Pengawasan Peradilan Administrasi terhadap Tindakan Pemerintah. Bandung: Alumni.

10. Fakrulloh, Z. A. (2015). Penegakan Hukum Sebagai Peluang Menciptakan Keadilan. Jurnal Jurisprudence, 2(1).

11. Government Regulation Number 16 the Year 2018 concerning Civil Service Police Unit.

12. Hasibuan, A. (2013). Peranan Satuan Polisi Pamong Praja (SATPOL-PP) Dalam Penegakan Peraturan Daerah Di Kota Medan. UMN. Medan: Al Washliyah.

13. Ilmar, A. (2014). Hukum Tata Pemerintahan. Jakarta: Kencana Prenadamedia Group.

14. Imparsial. (2012). Reformasi Peradilan Militer di Indonesia, Impersial (Nalar), Pedoman Teknis Administrasi dan Pemeriksaan di Sidang Pengadilan dalam Lingkungan Peradilan Militer. Jakarta.

15. Indonesia Criminal Code

16. Jemadu, A. (2012). Politik Global dalam Teori dan Praktek. Yogyakarta: Graha Ilmu.

17. Law Number 23 of 2014 concerning Regional Government.

18. Law Number 2 of 2002 concerning the Indonesian National Police.

19. Marzuki, P. M. (2011). Penelitian Hukum. Jakarta: Kencana Prenidamedia Group.

20. Mulyadi, H. M. A. (2016). Prinsip-Prinsip Negara Kesatuan dan Desentralisasi dalam Negara Republik Indonesia. Jakarta: Prestasi Putra Karya.

21. Nalle, V. I. W. (2016). Studi Sosio-Legal Terhadap Ketertiban Dan Ketentraman Di Kabupaten Sidoarjo. Jurnal Hukum E Pembangunan, 46(3), 383-409.

22. Oppusunggu, Y. U. (2008). Pertemuan Ilmu Hukum dan Sosiologi dalam Penerapan Lembaga Ketertiban Umum1. Law, Society E Development, 2(3).

23. Pribadi, S. (2015). Keamanan Dalam Negeri. Yogyakarta: Andi. 
24. Putra, A. K., \& Wicaksono, B. (2017). Studi Kewenangan Pemerintah Daerah: Penyidik Pegawai Negeri Sipil (Ppns) Satuan Polisi Pamong Praja di Kabupaten Pelalawan Tahun 2014-2016 (Doctoral dissertation, Riau University).

25. Qamar, N. (2011). Supremasi Hukum dan Penegakan Hukum. Jurnal Ilmiah Ishlah, 13(2).

26. Rahardi, P. (2007). Hukum Kepolisian (Profesionalisme dan Reformasi Polri). Jakarta: Laksbang Mediatama.

27. Soekanto, S., \& Mamudji, S. (2012). Penelitian Hukum Normatif. Jakarta: Raja Grafindo Persada.

28. Sulisdiani, I. (2012). Kinerja Satuan Polisi Pamong Praja Dalam Penertiban Pedagang Kaki Lima (PKL) Di Kota Pontianak. Jurnal PMIS-UNTAN-PSIS.

29. Suryanto. (2005). Penggambaran Permasalahan Penyelenggaraan Otonomi Daerah Dalam Media Cetak; Studi Analisis Wacana Kritis Terhadap Berita-Berita Otonomi Daerah. Jurnal Desentralisasi, 6(4), 36-56.

30. The 1945 Constitution of the Republic of Indonesia.

31. Tim Propatria Institute. (2012). Mencari Format Komprehensif Sistem Pertahanan dan Keamanan Negara. Jakarta: Propatria.

32. Ullman, R. (2013). Redefining Security. International Security, 8(1).

33. Waluyo, B. (2011). Penelitian Hukum Dalam Praktik. Jakarta: Sinar Grafika. 